Creative Commons User License: CC BY-NC-ND

Abstracted by: EBSCOhost, Electronic Journals Service (EJS),

Google Scholar, Journal Seek, Scientific Commons,

Food and Agricultural Organization (FAO), CABI and Scopus

http://eoi.citefactor.org/10.11226/v26i1
Journal of Agricultural Extension

Vol. 26 (1) January, 2022

ISSN(e): 24086851; ISSN(Print); 1119944X

http://journal.aesonnigeria.org

http://www.ajol.info/index.php/jae

Email: editorinchief@aesonnigeria.org

\title{
Knowledge of Eggplant Farmers on the proper use of Pesticides in Khartoum State, Sudan \\ https://dx.doi.org/10.4314/jae.v26i1.7
}

\author{
Abdelbagi, Azhari Omer \\ Department of Crop Protection, Faculty of Agriculture, University of Khartoum, Khartoum \\ North, Shambat, 13314, Sudan \\ Email: azharibagi@yahoo.com; Phone number: +249122180599
}

\section{Ismail, Rihab Eltahir Abdalla}

Ministry of Agriculture, Khartoum, Sudan

Email: rihabismail@yahoo.com; Phone number: +249122766596

\section{Ishag, Abd Elaziz Sulieman Ahmed}

Department of Crop Protection, Faculty of Agriculture, University of Khartoum, Khartoum North, Shambat, 13314, Sudan

Email: a.aziz30@gmail.com; Phone number: +249915378530; +82-10-4669-8530

\section{Hammad, Ahmed Mohammed Ali}

Department of Crop Protection, Faculty of Agriculture, University of Khartoum, Khartoum North, Shambat, 13314, Sudan

Email: ahmed7399@yahoo.com; Phone number:+249966687256

\section{Hur, Jang-hyun}

Department of Biological Environment, Kangwon National University, Chuncheon 24341, Republic of Korea

Email: hurpub303@gmail.com; Phone number: +82-(0)33-257-6441

\begin{abstract}
The knowledge of eggplant farmers on the proper use of pesticides was evaluated in Khartoum State. Questionnaire was distributed to farmers in North Nile Farms (NN), East Nile Farms (ENF), and West Nile Farms (WNF) to solicit information. Interviews and questionnaires revealed that there is a limited level of awareness among farmers. The majority (94\%) of farmers did not abide by recommended disposal procedures, they only damage and bury the containers inside the farms. The majority of farmers (66\%) were not aware of the safety period for any given product. The excessive use of pesticides in eggplant production and reliance only on pesticides as a pest management strategy calls for the implementation of IPM programs integrating the use of environmentally soft chemicals with other nonchemical control methods to manage pests and diseases. Safety periods should be carefully watched to reduce the level of residues in eggplant fruits below the acceptable level and to ensure sustainable and safe production.
\end{abstract}

Keywords: Eggplant-farmers, pesticide application, Sudan 
Creative Commons User License: CC BY-NC-ND

Abstracted by: EBSCOhost, Electronic Journals Service (EJS),

Google Scholar, Journal Seek, Scientific Commons,

Food and Agricultural Organization (FAO), CABI and Scopus

http://eoi.citefactor.org/10.11226/v26i1
Journal of Agricultural Extension

Vol. 26 (1) January, 2022

ISSN(e): 24086851; ISSN(Print); 1119944X

http://journal.aesonnigeria.org

http://www.ajol.info/index.php/jae

Email: editorinchief@aesonnigeria.org

\section{Introduction}

Vegetables are essential components of our diet due to their high nutritional value. They are important sources of vitamins such as vitamins C, A, B6, thiamine, niacin, and $\mathrm{E}$, and also being a source of minerals, and dietary fiber (Taha, Ayşe, Onur, \&Funda, 2018; $\mathrm{NIH}, 2021$ ). Vegetable production in Sudan is rapidly growing to meet the needs of the population intensity. Vegetables and fruits are widely grown in Sudan due to the availability of vast arable land, a reasonable supply of irrigation water, and suitable climatic conditions. The major types of vegetable crops in the Sudan include; Tomato (Lycopersicum esculentum Miller), onion (Allium cepa), Eggplant (Solanum melongena L), and cucurbits (FAOSTAT, 2021).

Eggplant generates high income for farmers, because of its repeated picking throughout the prolonged harvesting season. It is domestically known as Bedingan or Aswad and has several common names viz; aubergine, garden egg, and brinjal (Charu \& Dipankar 2020). It has different types, shapes, sizes, and colors (Charu \& Dipankar, 2020; José, Plazas, Sánchez-Mata, Cámara, \& Prohens, 2016). The popularity of eggplant in Sudan is mainly due to its low price, the diversity of methods in which it can be cooked, besides its ease to grow under harsh and warm climatic conditions (Ismail, 2016; Ministry of Agriculture, Sudan, 2019). The total area grown with eggplant in Sudan is about 3630 hectares with a total yield of 66600 tons (Food and Agriculture Organization (FAO), 2019). Worldwide, eggplant production has been gradually increasing comparable to the last decade, with major planting areas concentrated in China, India, Egypt, Turkey, and Japan (FAO, 2019).

Eggplant production negatively affects the environment because of its heavy requirement for pesticides, especially in Asia. In Sudan as well as in many developing countries insecticides are frequently applied during the growth period and sometimes even at the fruiting stage. Indiscriminate use of pesticides mainly at the fruiting stage and non-adoption of pre-harvest interval leads to accumulation of pesticides in the consumable parts (Alengebawy 2021; FAO and World Health Organization (WHO), 2020).

Previous works indicated the limited knowledge of vegetable growers in Khartoum and Gezira states, about the safe use of pesticides and their expected hazard to human health and the environment (Ismail, 2016; Awad, Adam, Ahmed, Abd Elaziz, Elsadig, Asia \& Azhari, 2018a; Awad, Adam, Ahmed, Abd Elaziz, Azhari, Ali, Elsadig, Asia, \& Ahmed, 2019). Extension services available to farmers were sub-standard and require more focus on current and future development projects. Further measurable levels of malathion, fenitrothion, chlorpyrifos, Profenofos, dimethoate, heptachlor, diazinon, ethephon, oxyfluorfen, omethoate, $\alpha$ endosulfan, $\beta$ endosulfan, imidacloprid and 2, 4-D in were detected in samples of fresh fruits from Sudan (Hammad, Abdelbagi, Ishag, Asma, \& Mark; 2017; Awad, Adam, Ahmed, Abd Elazizl, Elsadig, \& Asia, 2018b; Abdelbagi, Ismail, Ishag, \& Hammad, 2020). Aldawi, Abdelbagi, Ishag, \& Hammad, (2019), Musa, Hammad, Abdelbagi, \& Ishag (2019), and Abdallah, Abdelbagi, Ishag, \& Hammad (2020) reported that prewashing of fruits with water reduces the level of pesticide residues in fruits of vegetables. Based on limited knowledge of farmers about safety, their indiscriminate and heavy use of 
Creative Commons User License: CC BY-NC-ND

Abstracted by: EBSCOhost, Electronic Journals Service (EJS),

Google Scholar, Journal Seek, Scientific Commons,

Food and Agricultural Organization (FAO), CABI and Scopus

http://eoi.citefactor.org/10.11226/v26i1
Journal of Agricultural Extension

Vol. 26 (1) January, 2022

ISSN(e): 24086851; ISSN(Print); 1119944X

http://journal.aesonnigeria.org

http://www.ajol.info/index.php/jae

Email: editorinchief@aesonnigeria.org

pesticides on eggplant, this study assessed farmers' knowledge about aspects of safety; and proper use of pesticides.

\section{Methodology}

Nine locations representing the three major eggplant production areas in Khartoum state were chosen for the study. The chosen locations were; north Nile farms (EI Sagai, Karari, Elkhililah) (15.6726 N, 32.5376 E, 15.5304 N, 32.5576 E), east Nile farms (Toti, Soba Elhila, El Alilafoon) (15.5133 N, $32.6534 \mathrm{E})$, and West Nile farms (JabalAwlia, Elgmoiah, Omdawnban) (15.2578 N, $32.5015 \mathrm{E})$. The study area in the three sites is close to the Main Nile and/or to its main tributaries (the Blue and White Niles) where soil is silt loam with shallow water table and poor savannah climate. The maximum and minimum daily temperatures range from $36-40^{\circ} \mathrm{C}$ in summer and $17-20^{\circ} \mathrm{C}$ in winter. The rainy period extends from July to September with average rainfall of 600 to $850 \mathrm{~mm}$.

Fifty eggplant farmers in each of nine locations in Khartoum state; north Nile, east Nile farms, and West Nile farms were interviewed about safety aspects and proper use of pesticides through the distribution of carefully designed questionnaires reflecting the main practices related to pesticide use observed by farmers in various areas. The questionnaire included types of crops grown, major methods used the control of pests and diseases, basis of spray decisions, source of pesticides, pesticide and container disposal, pesticide waste management, cultural practices, knowledge of safe use of pesticides, method of application, number of spraying per season, interval between sprayings, abiding by recommended dose, personal protection, health hazard and safety period.

The sample size was determined following the method described by Awad et al., (2018a);

$\mathrm{n}=\mathrm{N} / 1+\mathrm{e}(\mathrm{N}-1)$

Where: $\mathrm{n}=$ the required sample size, $\mathrm{N}=$ total population (49 farms) e = error $(p=0.05)$. Substituting the $N$ and e values in the equation; then: $n=49 / 1+(0.05)$ ${ }^{*}(49-1)=14.4$. After rounding up, this will be equal to 14 farms which were then used as the desired sample.

Questionnaire was distributed to farmers in the selected farms. Completed questionnaires were carefully revised and the data were analyzed using SPSS software version 16 . The relationship between the independent variables and the outcomes of interest in the bi-variants were determined using chi-square tests. Results of relationship with $p<0.05$ were considered statistically significant.

\section{Results and Discussion}

\section{Major Pests and Diseases of Vegetables Identified by Farmers}

The results of the study show that the main pests affecting agricultural crops, and need chemical control included; aphids (32\%), whiteflies (21.3\%), acaros (13.3\%), and thrips (6\%) (Fig. 1). 


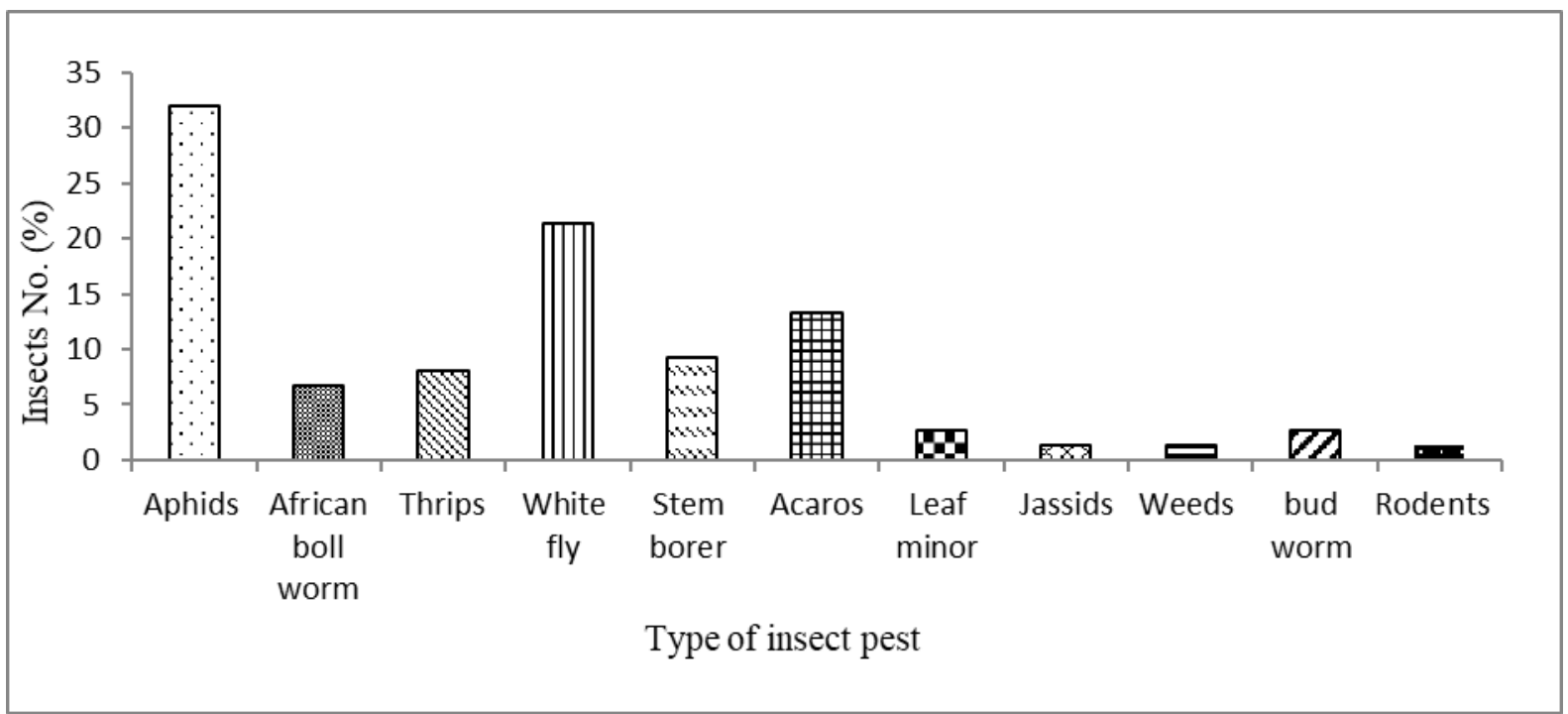

\section{Figure 1: Most important insect pests identified by the farmers include}

The main diseases included powdery mildew, leaf curl, late blight, root rot, bacterial wilt, stem borer, downy mildew, leaf spot, and blight. Attempts to control eggplant pests currently entail excessive use of pesticides. Intensive pesticide use in eggplant increases the cost of production, making this vegetable expensive for low-income consumers. Pesticide misuse and residues pose serious risks to the health of growers, consumers, and the environment (Shammi Sultana, Hasan, Mostafizur, Islam, Bodrud-Doza, \& Uddin, 2020). Prolonged exposure of the same population of pests to the same compound has led to the establishment of resistant populations. Further, minor pests may change status to major pests owing to the elimination of their natural predators as a result of intense pesticide application. Misuse of pesticides negatively affects non-target organisms (Vumilia, Gaspary, Julius \& Armachius, 2019).

\section{Commonly used Pesticides}

The result indicated that the main pesticides used in pest control and sprays per season were, omethoate, imidacloprid, vertimec, malathion, diazinon, carbaryl, triadimefon, dimethoate, and endosulfan (Fig. 2). 


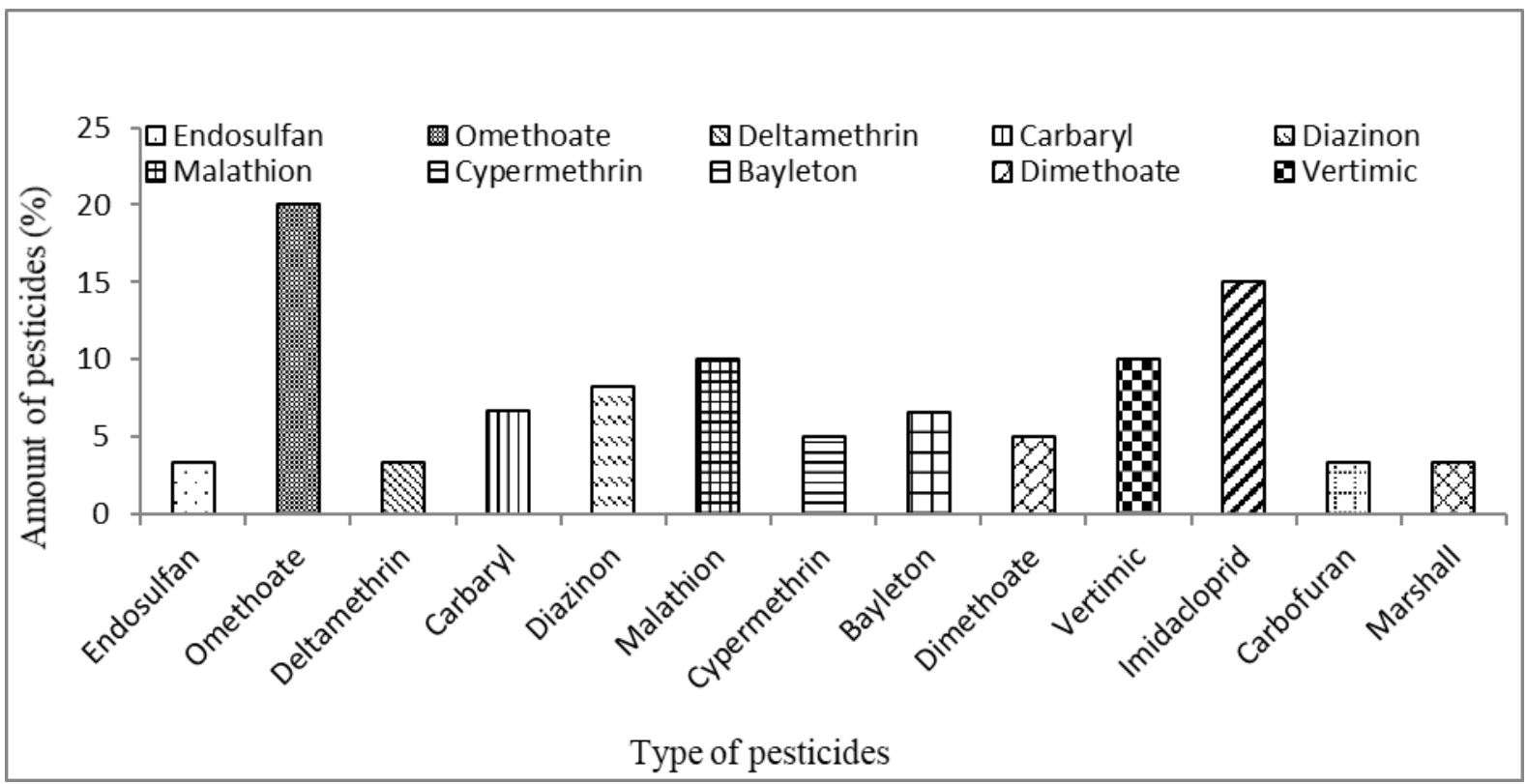

\section{Figure 2: Most commonly used pesticides}

These pesticides were registered for use in Sudan although some were not registered for vegetables such as endosulfan (NPC, personal communication). The use of such insecticides on vegetables may pose a hazard to consumers and nontarget organisms. Sudan has a long history of pesticide dependence and pesticiderelated problems. Sudan began large-scale cotton production under British colonialism in the 1920s and started applying pesticides to its cotton plantations in the 1940s. According to the previous work conducted by Brzozowski, \& Michael (2018), over-reliance on pesticides has caused severe problems, including outbreak of secondary pests, pesticide resistance, increased costs of production, and human and environmental poisonings. Insecticides are relatively cheap, fast working, and rather easy to apply.

\section{Chemical Control Decision}

The decision to use chemical control is based in most cases on general observations $(26 \%)$ and past experience (20\%), with a small fraction (10\%) basing their decisions on preventive spray programs and pest surveys (Table 1).

Table 1: Base for chemical control decision

Decision of chemical control Percentage (\%)

According to survey of pests

10

General observation

For prevention purposes

According to past experience

Recommendation by Agric.

Dept. 
Since many farmers had a low level of education and suffer from the low level of extension service available to them, this may lead to significant misuse of pesticides with adverse effects on the environment (Awad et al., 2018a; 2018b). Chemical pest control became an essential component of the vegetable production process. The farmers rely totally on pesticides to get quick action of healthy crop; this may be explained by the low level of extension services available to farmers (Ismail, 2016).

Time of application: Sixty-Four Percent of the farmers wait for a suitable time to spray the pesticides during the day and they considered morning time as the best time for spraying due to the low temperature, while the rest (26\%) prefer to spray in the evening because they think it is the appropriate time of pests' existence according to their information (Fig. 3).

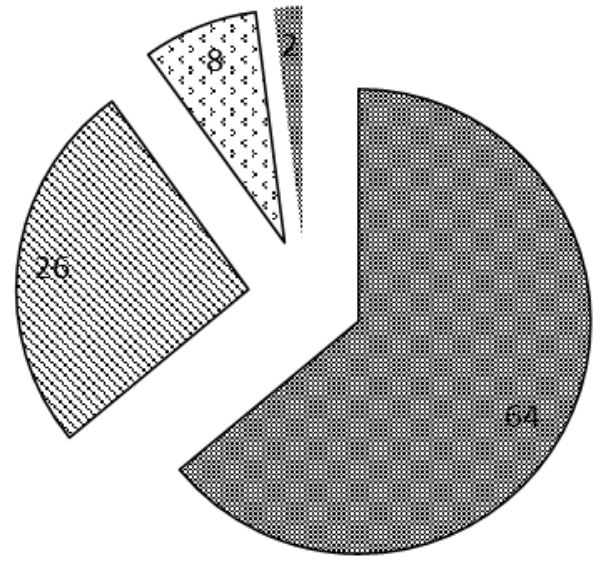

․ㅐㅆ Morning

Nevening

그 At low temperature condition

At stable wind

\section{Fig. 3: Time of application claimed by the farmers}

Another factor that determines the spray time is the wind current as some farmers prefer to spray in calm wind conditions. Spray time during the day could affect the efficacy of the application as it affects pest activity as well as the stability of the applied pesticide. Temperature and wind current as well as other climatic factors differ during the day and could interfere with pest activity and the stability of the applied pesticide (Muhammad \& Albert, 2016; Su-Hyeon, Chang-Hun, Ki-Hun \& Sang-Hee, (2016). High temperatures affect the rate of volatilization of most insecticides and retard insects' activity. Insects hide in their host, soil, or under the leaves and therefore may not be accessible to applied pesticide and therefore spraying at high temperatures becomes ineffective. Further applying pesticides during the cooler hours of the day could reduce the danger of leaf scorching according to Fishel \& Ferrell, (2019).

\section{Number of Sprays and Interval between Sprays}

Table 2 shows that the number of sprays claimed by some respondents may reach up to 15 per season, but most of the respondents claimed 1-3 sprays during the season. 
Table 2: Number of spray and intervals between spray indicated by the respondents

\begin{tabular}{lll}
\hline Item & \multicolumn{2}{l}{ Farmer } \\
\hline & Category & Percentage \\
\multirow{4}{*}{ No. of sprays } & $1-3$ & 36 \\
& $4-7$ & 20 \\
& $8-11$ & 20 \\
\multirow{4}{*}{ Interval between sprays } & $12-15$ & 28 \\
& After one week & 38 \\
& After two weeks & 26 \\
& After three weeks & 36 \\
\hline
\end{tabular}

Thirty-eight percent of the farmers claimed that they apply pesticides weekly while $26 \%$ spray every two weeks and $36 \%$ of the farmers spray every three weeks. Growers in many of the developing countries depend much on pesticides to protect their crops. For instance, sprays may reach 56 times per season in a certain area of the Philippines; the total quantity of pesticide used per hectare of eggplant was about 41 liters of different brands (Navasero, 2017). Furthermore, in Bangladesh, the spray reaches 80 times in a cropping season (Ahmed, Hoddinott, Abedin, \& Hossain, 2021). The practice of overdosing and frequent spraying may cause many negative consequences in health and environment as well as in economic losses. Several national authorities set strict national and/or adopt international MRLs for the domestic, imported, and exported commodities which could result in rejection of consignments with violative levels of pesticides residues (>MRLs), a case which may result in severe economic losses especially in perishable products such as vegetables (United States International Trade Commission, 2020).

Following Instructions During Use: As shown in Table 3 the majority (86\%) of the respondents claim to read instructions before use and consider it the main source of information available with the package.

\section{Table 3: Following instructions during use}

\begin{tabular}{llc} 
& Answer & Farmers \\
\cline { 2 - 2 } & Farmers who read instructions & Percentage (\%) \\
Read instructions before use & Farmers who don't read the instruction & 86 \\
& Illiterate & 14 \\
Reasons which prevented farmers to & Not important & 10 \\
read the label & past experience & 2 \\
& Respondents who follow instructions during & 2 \\
Follow instructions during the & application & 60 \\
application & Respondents do not follow instructions during & 40 \\
Reasons why they don't follow the & application \\
instructions & Unavailability & 36 \\
\hline
\end{tabular}

Those who do not read it attributed this to literacy or being acquainted with information from past experience. The majority of the respondents claim to follow safety instructions (60\%) and those who do not follow it attributed this to unavailability of the protective clothes. None of the farmers claimed to possess 
Creative Commons User License: CC BY-NC-ND

Abstracted by: EBSCOhost, Electronic Journals Service (EJS),

Google Scholar, Journal Seek, Scientific Commons,

Food and Agricultural Organization (FAO), $\mathrm{CABI}$ and Scopus

http://eoi.citefactor.org/10.11226/v26i1
Journal of Agricultural Extension

Vol. 26 (1) January, 2022

ISSN(e): 24086851; ISSN(Print); 1119944X

http://journal.aesonnigeria.org

http://www.ajol.info/index.php/jae

Email: editorinchief@aesonnigeria.org

proper protective clothes with most wears causal dresses during spraying which cannot protect most of their bodies from contamination by pesticides. Pesticide product labeling statements are intended to alert the farmers to safety precautions and environmental concerns that the pesticide products may pose. Available protective clothings are designed for use in temperate climates and is not suitable for the tropics or subtropics, where heat and humidity are high. Many of the farmers wear special clothes devoted only for spraying of crops, which may partially reduce severe discomfort or physical distress in hot conditions. Therefore, cooler day hours are recommended for pesticide application. Protective clothing's could protect pesticides applicators and handlers if they follow all safety instructions in the container labeling as mentioned by the USA Environmental Protection Agency, (2020).

Following Recommended Dose: The majority of the farmers $(60 \%)$ use the recommended dose, while $40 \%$ do not use it. Those who do not follow the recommended dose explained this by assurance of control or past experience. Most farmers use measuring cylinders to measure the dose in case of small packages, while others use empty tomato paste cans in measuring the dose to be applied. The majority of the farmers who follow the recommended dose $(56 \%)$ depend on the technical staff's advice for determining the correct dose, but unfortunately, they are not always available in their location and they used empty tomato paste cans for measuring the dose to be applied. Similar findings were reported by Ismail, (2016) who mentioned that most farmer uses cans of tomato paste as a measure of the dose of pesticides (empty tomato paste can is approximately $70 \mathrm{cc}$ ). Farmers found these containers as available practical measure however in recent years tomato paste cans do not have a standard size and different sizes of these cans are used by different producers and this could confuse farmers who use them as a measure of pesticides assuming all containers have a standard size of $70 \mathrm{cc}$.

Concern about Quality: About $90 \%$ of the farmers claim to purchase pesticides in original package which may indicate, their high concern about the quality (Table 4), this agrees with Ismail, (2016) who stated that most of the responding farmers claim to have a high concern about quality by looking for fresh and labeled stocks.

Table 4: Time of pesticide purchase and originality of stocks

\begin{tabular}{llc}
\hline Pesticide use characteristics & Response & $\begin{array}{c}\text { Farmers } \\
\text { percentage (\%) }\end{array}$ \\
\hline $\begin{array}{l}\text { When farmers purchase their } \\
\text { stocks of pesticides }\end{array}$ & At the beginning of season & 46 \\
& $\begin{array}{l}\text { During the season } \\
\text { End of the season }\end{array}$ & 4 \\
& Appearance of infestation & - \\
Purchase the & $\begin{array}{l}\text { The farmers who buy the pesticides in its } \\
\text { original containers }\end{array}$ & 50 \\
& Farmers who buy repacked pesticides & 90 \\
\hline
\end{tabular}


Creative Commons User License: CC BY-NC-ND

Abstracted by: EBSCOhost, Electronic Journals Service (EJS),

Google Scholar, Journal Seek, Scientific Commons,

Food and Agricultural Organization (FAO), CABI and Scopus

http://eoi.citefactor.org/10.11226/v26i1
Journal of Agricultural Extension

Vol. 26 (1) January, 2022

ISSN(e): 24086851; ISSN(Print); 1119944X

http://journal.aesonnigeria.org

http://www.ajol.info/index.php/jae

Email: editorinchief@aesonnigeria.org

According to Ismail, (2016), most farmers read the label before the use of pesticides and care about signs and pictograms. Pesticide product labels provide important information about how to safely handle and use pesticide products (EPA, 2016).

The investigation reveals that most of the farmers $(96 \%)$ reject buying expired pesticides, while $4 \%$ claimed to do so. This again confirms their high concern about quality.

Disposal of empty containers, Safety period, and warning signs: The majority of farmers $(94 \%)$ do not abide by the recommended disposal procedures of empty containers; they claim to damage and bury the containers inside the farms. The majority of the farmers do not put warning signs on treated farms and they explain this by the fact that they live near their farm and can guard them from people and animals.

The vast majority of the farmers $(66 \%)$ are not aware of the safety period for any given product, while $34 \%$ are aware of the safety period. According to Mwanja, Jacobs, Mbewe, Munyinda, (2017), vegetables are harvested shortly after pesticide application which leads to their contamination by pesticide residues which could be hazardous for consumers and may lead to rejection of exports and by the way could cause economic losses. Generally, pesticides applied to crops can leave harmful residues. In particular, the organochlorine pesticides persist in foodstuffs for a considerable period (Nurgul, Bakirhan, Bengi, Ozkan, 2018). Generally, the study revealed the limited knowledge of farmers about the safe use of pesticides and the limited training programs available to them. This calls for immediate extension interventions to farmers in the study area.

Awareness About Pesticide Hazards: The results reveals that $44 \%$ of the farmers believe that there is no health hazard associated with the application of pesticides; about $26 \%$ claimed very low hazard, $22 \%$ indicated moderate hazard, whereas only $8 \%$ believe that pesticide use is highly hazardous. This low level of awareness may lead to the misuse of pesticides. The low level of awareness may be attributed to limited extension services available to farmers from agricultural officials and/or sales company advisers. The shortage of qualified extensionists and training programmers makes extension service inadequate. Similar results were reported by Davis, \& Terblanché, (2016) who also reported the absence or the weak role played by the extension service.

Knowledge of economic threshold level: A greater proportion (44\%) of farmers, including those who have long experience in farming practice, had no idea about the economic threshold level of a pest and they start using chemical control when they observe any level of the pests or disease on the farm. This may increase the production cost and may lead to spread of the pests due to the reduction of their natural enemies (Fadlelmawla, Abdelbagi, Ishag, Hammad, \& Hur 2020; 2021). Ignorance about IEL may indicate the low level of extension services available to farmers.

Training programmes received by farmers: The survey showed that $47 \%$ of the farmers did not receive training courses on the safe and effective use of pesticides; 
Creative Commons User License: CC BY-NC-ND

Abstracted by: EBSCOhost, Electronic Journals Service (EJS),

Google Scholar, Journal Seek, Scientific Commons,

Food and Agricultural Organization (FAO), CABI and Scopus

http://eoi.citefactor.org/10.11226/v26i1
Journal of Agricultural Extension

Vol. 26 (1) January, 2022

ISSN(e): 24086851; ISSN(Print); 1119944X

http://journal.aesonnigeria.org

http://www.ajol.info/index.php/jae

Email: editorinchief@aesonnigeria.org

therefore, their knowledge about the safe use of pesticides is quite limited. The main organizers of training are Plant Protection Directorate (PPD) and the Extension Department. Training of farmers is very important for farmers and consumer safety as well as for the protection of contamination of the environment as reported by many authors (Awad et al., 2018, 2019).

\section{Conclusion and Recommendations}

A low level of knowledge about safety aspects and hazards of pesticides and limited extension services were noted by responding farmers in the study area. The pesticide spraying is based on general observations and farmers' experience. Farmers do not abide by recommended disposal procedures, they only damage and bury the containers inside the farms. Training of farmers on safety aspects should be done through intensive extension services (e.g. farmers' field schools). Protective clothing and safety equipment's that suit the local climate should be made available to farmers.

\section{References}

Abdallah, H., Abdelbagi, A., Ishag, A., \& Hammad A. (2020). Residues of some of the commonly used insecticides on snake cucumber (Cucumis melo L., var. flexuosus) grown in Khartoum State, Sudan. EC Pharmacology and Toxicology, 8(4), 46-58.

Abdelbagi, A., Ismail, R., Ishag, A., \& Hammad, A. (2020). Pesticide residues in eggplant fruit from Khartoum State, Sudan. Journal of Health \& Pollution, 10 (25), 1-11.

Ahmed, A. U., Hoddinott, J., Abedin, N., \& Hossain, N. (2021). The Impacts of GM foods: results from a randomized controlled trial of Bt eggplant in Bangladesh. Amer. Journal of Agricultural Economic, 103: 1186-1206. https://doi.org/10.1111/ajae.12162

Aldawi, A, Abdelbagi, A., Ishag, A., \& Hammad, A. (2019). The Level of pesticide residues in cucumber fruits collected from central vegetable markets in Khartoum state. EC Pharmacology and Toxicology, 7(1), 60-68.

Alengebawy, A., Abdelkhalek, S. T., Qureshi, S. R., \& Wang, M-Q, (2021). Heavy metals and pesticides toxicity in agricultural soil and plants: ecological risks and human health implications. Toxics 9(3): 42. https://doi.org/10.3390/toxics9030042

Awad, M, Adam, M, Ahmed, H., Abd Elaziz, I., Azhari, A., Ali, E., Elsadig, E., Asia, D., \& Ahmed, G. (2019). Knowledge, attitudes and practices of pesticide's sprayers towards pesticides use and handling in greenhouse farms, Sudan. International Journal of Management and Commerce Innovations, 6(2), 840-850.

Awad, M., Adam, M., Ahmed, H., Abd Elaziz, I., Elsadig, E., Asia, D., \& Azhari, A. (2018a). Knowledge, attitudes and practices of farmers towards pesticides use and handling in greenhouse farms, Sudan. International Journal of Research - GRANTHAALAYAH, $6(9), 520-534$.

Awad, M., Adam, M., Ahmed, H., Abd Elazizl., Elsadig, M., \& Asia, D. (2018b). Pesticide residues detected on tomato and cucumber fruits grown in greenhouse farms in Khartoum State, Sudan. International Journal of Life Sciences Research, 6(3), 472481.

Brzozowski, L., Mazourek, M. (2018). A sustainable agricultural future relies on the transition to organic agroecological pest management. Sustainability. 10(6): 1-25. https://doi.org/10.3390/su10062023.

Charu, L. M., Dipankar K., (2020). Chapter 16 - Eggplant, Editor(s): Amit K. Jaiswal, Nutritional composition and antioxidant properties of fruits and vegetables, Academic Press, 2020: 273-287, https://doi.org/10.1016/B978-0-12-812780-3.00016-7. 
Creative Commons User License: CC BY-NC-ND

Abstracted by: EBSCOhost, Electronic Journals Service (EJS),

Google Scholar, Journal Seek, Scientific Commons,

Food and Agricultural Organization (FAO), $\mathrm{CABI}$ and Scopus
Journal of Agricultural Extension

Vol. 26 (1) January, 2022

ISSN(e): 24086851; ISSN(Print); 1119944X

http://journal.aesonnigeria.org

http://www.ajol.info/index.php/jae

Email: editorinchief@aesonnigeria.org

Davis, K. E., \& Terblanché, S. E. (2016). Challenges facing the agricultural extension landscape in South Africa, quo vadis?. South African Journal of Agricultural Extension. 44(2): $231 \quad-247 . \quad$ DOI: http://dx.doi.org/10.17159/2413$3221 / 2016 / v 44 n 2 a 428$.

Fadlelmawla, M., Abdelbagi, A., Ishag, A., Hammad, A., \& Hur, J-H. (2020). Effects of nitrogen fertilization and some non-conventional insecticides on sap sucking pests and yield of transgenic Bt cotton in Sudan. International Journal of Tropical Insect Science 40(4), 1-14 https://doi.org/10.1007/s42690-020-00345-y.

Fadlelmawla, M., Abdelbagi, A., Ishag, A., Hammad, A., \& Hur, J-H. (2021). Effects of nitrogenous fertilization and some insecticides on the natural enemies of transgenic Bt Cotton pests. EntomoBrasilis 14: e948. doi: 10.12741/ebrasilis.v14.e948.

Food and Agriculture Organization \& World Health Organization of the United Nations (FAO \& WHO). (2020). Pesticide residues in food 2019 - Report 2019 - Joint FAO/WHO Meeting on Pesticide Residues. Rome.

Food and Agriculture Organization Corporate Statistical Database, FAOSTAT (2021) Crops [Internet]. Rome: The food and agriculture organization of the United Nations [Accessed 2021, 2021 Oct 30]. Available from: http://www.fao.org/faostat/en/\#data/QC.

Fishel, F. M., \& Ferrell, J. A. (2019). Managing pesticide drift. The Institute of Food and Agricultural Sciences (IFAS). Pesticide Information Office Document series PI232 115 Available website at https://edis.ifas.ufl.edu.

Food and Agriculture Organization (FAO), (2019). Statisticalyearbookproduction.http/fao.org.

Food and Agriculture Organization of United Nations (FAO), (2019). Statistics division http://www.fao.org/faostat/en/\#data/QC.

Hammad, A., Abdelbagi, A., Ishag, A., Asma, A., \& Mark, L. (2017). Determination of residues levels of seven pesticides in tomatoes samples taken from three markets in Khartoum State, Sudan.9th Int'l Conf. on Research in Chemical, Agricultural, Biological \& Environmental Sciences (RCABES-2017) Nov. 27-28, 2017 Parys, South Africa.

International Service for the Acquisition of Agri-biotech Applications \& HE Southeast Asian Regional Center for Graduate Study and Research in Agriculture Biotechnology Information Center (2020). Questions and answers about the fruit and shoot borer resistant eggplant (Bt Talong), the first Filipino biotech product. https://www.isaaa.org/blog/entry/default.asp?BlogDate=9/23/2020.

Ismail, E. (2016). Pesticide residues in eggplant (and evaluation of farmers knowledge about proper use of pesticides in Khartoum State. M.Sc. Thesis, University of Khartoum.

José, R., San, Plazas, M., Sánchez-Mata, M. C., Cámara, M., Prohens, J. (2016). Diversity in composition of scarlet ( $S$. aethiopicum) and gboma ( $S$. macrocarpon) eggplants and of interspecific hybrids between $S$. aethiopicum and common eggplant ( $S$. melongena). Journal of Food Composition and Analysis, 45: 130-140.

Ministry of Agriculture, (2019). Annual report. Khartoum, Sudan,

Muhammad, S., \& Albert, L. (2016). Indoor risks of pesticide uses are significantly linked to hazards of the family members. Cogent Medicine, 3(1): 1-10. DOI: 10.1080/2331205X.2016.1155373.

Musa, N., Hammad, A., Abdelbagi, A., \& Ishag, A. (2019). Pesticides residues in samples of sweet peppers (Capsicum annum) from Khartoum State, Sudan. EC Pharmacology and Toxicology, 7(7), 568-576.

Mwanja, M., Jacobs, C., Mbewe, A. R., \& Munyinda N. S. (2017). Assessment of pesticide residue levels among locally produced fruits and vegetables in Monze district, Zambia. Food Contamination, 4(11). 2-9. https://doi.org/10.1186/s40550-017-0056-8. 
Creative Commons User License: CC BY-NC-ND

Abstracted by: EBSCOhost, Electronic Journals Service (EJS),

Google Scholar, Journal Seek, Scientific Commons,

Food and Agricultural Organization (FAO), CABI and Scopus

http://eoi.citefactor.org/10.11226/v26i1
Journal of Agricultural Extension

Vol. 26 (1) January, 2022

ISSN(e): 24086851; ISSN(Print); 1119944X

http://journal.aesonnigeria.org

http://www.ajol.info/index.php/jae

Email: editorinchief@aesonnigeria.org

Navasero, M. (2017). Bt Eggplant \& the science behind the technology: The place of Bteggplant in IPM in eggplant. Conference: Public Dialogue on Bt Eggplant At: Umali Auditorium, SEARCA Headquarters, College, Laguna, Philippines.

$\mathrm{NIH}$ (2021). National center for complementary and integrative health. \{Access 30 Oct. 2021\} https://www.nia.nih.gov/health/vitamins-and-minerals-older-adults.

Nurgul, K., Bakirhan, Bengi U., Ozkan S. A., (2018). Chapter 5 - The detection of pesticide in foods using electrochemical sensors, Editor(s): Alexandru Mihai Grumezescu, Alina Maria Holban, Food Safety and Preservation, Academic Press, 2018, Pages 91-141, https://doi.org/10.1016/B978-0-12-814956-0.00005-6.

Shammi, M., Sultana, A., Hasan, N., Mostafizur, R., Islam, S., Bodrud-Doza, Uddin, K. (2020). Pesticide exposures towards health and environmental hazard in Bangladesh: A case study on farmers' perception, Journal of the Saudi Society of Agricultural Sciences, 19(2): 161-173, https://doi.org/10.1016/j.jssas.2018.08.005.

Su-Hyeon, K., Chang-Hun, L., Ki-Hun, K. \& Sang-Hee, J. (2016). Comparative estimation of exposure level and health risk assessment of highly produced pesticides to agriculture operators by using default dermal absorption rate or actual measurement values. Biomedical Science Letters, 22(4): 199 206. http://dx.doi.org/10.15616/BSL.2016.22.4.199.

Taha, G. Ü., Ayşe, N. S., Onur Ç., Funda P. Ç. (2018). Role of vegetables in human nutrition and disease prevention, vegetables - importance of quality vegetables to human health, Md. Asaduzzaman and Toshiki Asao, IntechOpen, DOI: 10.5772/intechopen.77038. Available from: https://www.intechopen.com/chapters/61691.

The World Bank, (2021). https://data.worldbank.org/indicator/SP.POP.GROW

United states international trade commission (2020) Global economic impact of missing and low pesticide maximum residue levels, Vol. 1. Washington, DC 20436, P. 340.

USA Environmental protection Agency (2020). Personal protective equipment for pesticide handlers. $\quad$ https://www.epa.gov/pesticide-worker-safety/personal-protectiveequipment-pesticide-handlers\#duties.

USA Environmental protection Agency (2021). Label review manual, pp 289.

Vumilia, L. Z., Gaspary, M., Julius, E. N., \& Armachius, J. (2019). Pesticide regulations and their malpractice implications on food and environment safety. Cogent Food \& Agriculture, 5(1): 1601544, DOI:10.1080/23311932.2019.1601544. 